\title{
The Effect of Group Cognitive Behavior Therapy on Behavior Changes in Adolescents Risked of Drug Abuse in Dharmasraya Regency
}

\author{
Wisdia Lola Erwinda ${ }^{a}$, Susmiati ${ }^{b}$, Heppi Sasmita \\ ${ }^{a}$ Dinas Kesehatan Kabupaten Dharmasraya, Jl.Pesanggerahan No.17 Sungai Dareh Kec.Pulau \\ Punjung, Kabupaten Dharmasraya, 27573, Indonesia \\ ${ }^{b}$ Fakultas Keperawatan Universitas Andalas, Padang, 25163, Indonesia \\ 'Politeknik Kesehatan Kemenkes RI, Padang, 25146, Indonesia \\ e-mail korespondensi: lolafaisal_nurse@yahoo.com
}

\begin{abstract}
Various problems in adolescents are increasing nowadays, one of them is drug abuse. Considering the condition of Dharmasraya Regency, which is vulnerable to drug trafficking, a prevention act to drug abuse behavior among adolescents is required. This study aimed to determine the effect of Group Cognitive Behavior Therapy $(G C B T)$ on behavior changes in adolescents risked of drug abuse in Dharmasraya Regency. This study design was a Quasi Experimental Research with Pretest and Posttest With Control Group. The samples were 64 people consisting of 32 people in the control group and 32 people in the intervention group. The results of this study indicated that there was a significant influence on behavior changes in adolescent in the intervention group. Meanwhile, there was no significant differences happened in the control group. Therefore, (GCBT) can be applied to change the behavior of adolescents risked at drug abuse. It is expected that GCBT can be implemented at schools in collaboration with the health department to prevent drug abuse on adolescents.
\end{abstract}

Keywords: Adolescents, Behavior, Drug Abuse, GCBT

\begin{abstract}
Abstrak
Berbagai permasalahan pada remaja semakin meningkat, salah satunya adalah penyalahgunaan NAPZA. Melihat kondisi daerah Kabupaten Dharmasraya yang sangat rawan dan rentan sekali dengan kasus peredaran narkoba diperlukan cara untuk mencegah perilaku penyalahgunaan NAPZA pada remaja. Tujuan penelitian ini adalah untuk mengetahui pengaruh Group Cognitive Behaviour Therapy (GCBT) terhadap perubahan perilaku remaja berisiko penyalahgunaan NAPZA pada remaja di Kabupaten Dharmasraya. Desain Penelitian ini adalah Quasi Eksperimen PreTest PostTest With Control Group dengan jumlah sampel 64 orang yang terdiri dari 32 kelompok kontrol dan 32 kelompok intervensi. Hasil penelitian pada kelompok intervensi dan remaja akhir menunjukkan ada pengaruh yang signifikan terhadap perubahan perilaku remaja. Sedangkan pada kelompok kontrol dan pada remaja awal tidak terdapat perbedaan yang signifikan. Dapat disimpulan bahwa GCBT dapat digunakan untuk merubah perilaku remaja berisiko penyalahgunaan NAPZA Diharapkan GCBT dapat dilaksanakan di sekolah-sekolah bekerjasama dengan dinas kesehatan untuk mencegah perilaku penyalahgunaan NAPZA pada remaja.
\end{abstract}

Kata kunci: Adolescents, Behavior, Drug Abuse, GCBT

\section{INTRODUCTION}

According to WHO (World Health Organization) (2015), adolescence is a development phase between childhood and adulthood, lasting between the ages of 10 to 19 years. Adolescence becomes the most important period because it is said to be a period of self-identity search (Hurlock, 2003). Health problems on adolescents are also one of the crucial problems in the life cycle. One of the crucial behavioral risk factors in adolescents' health status is the alcohol consumption and the use of illegal drugs or substance abuse known as Narcotics, Psychotropic and other addictive substances (NAPZA) (Research and Development Ministry of Health, Republic of Indonesia, 2015).

The behavior of drug abuse (NAPZA) are increasing year by year. According to a report by Nations Office on 
Drugs And Crime (UNODC) 2018, an estimated of 450,100 people worldwide died from drugs in $2015 ; 167,750$ of that number were included in opioid drug abuse. Asia and Africa became the most destinations in the spread of addictive substances in 2015. Specifically in Asia, Southeast Asia contained the most addictive substance users, including Singapore, Malaysia and Indonesia. In Indonesia as many as 40 people die because of drugs every day (National Narcotics Agency, 2018). Drug abuse still becomes a serious problem faced by countries in the world including Indonesia.

The government states that Indonesia was in a state of emergency in the dangers of narcotics and drug abuse. The number of drug abuse in Indonesia was approximately 3.8 million to 4.1 million people in the 10-59 years age group in 2014. It is estimated that the number of drug abuse will increase to 5 million by 2020 . This makes Indonesia as a top rank country in narcotics circulation (BNN, 2015).

Several studies revealed that drug abuse adversely affects the behavior and cognitive function of its users (Thomas \& Rockwood, 2001). The impacts on behavior include the emergence of depressive behavior (self-isolation from the environment, lack of self-care activities), aggressive behavior and antisocial behavior (disturbing the orders). Meanwhile, the major impact on cognitive functions is the emergence of negative thoughts such as self-believe as a useless person, feeling guilty, powerless and can not be trusted. In addition, drug users generally deny that they are having problems (denial) or underestimate the problems they have (minimization) (Susanti, 2010).

An anticipation action, such as increasing the promotion and prevention efforts of drug abuse, can be conducted to tackle drug abuse. The condition of Dharmasraya Regency which is located in the border area of West Sumatra Province with Muaro Bungo Regency in Jambi Province and Teluk Kuantan Regency in Riau, is vulnerable of drug trafficking. Dharmasraya Regency consists of various ethnicities and becomes a crossing area of Sumatra with a population of 212,734 people; $27 \%$ of them are teenagers (12-19 years old).

Considering this number, several programs such as School's Health Clinic, Youth Information and Counseling Centers and Youth Health Care Services Programs have been administered for the adolescents' health. One of the agenda to prevent drug abuse among adolescents in Dharmasraya Regency is health education for school aged children about the drug abuse. However, the number of behavior risked of drug abuse is increasing every year. So far, psychotherapy such as Cognitive Behavior Therapy (CBT) has never been accomplished to overcome the problem of adolescents risked at drug abuse.

CBT refers to a psychosocial therapy that integrates behavior modification through a cognitive restructuring approach (Martin, P, 2010). The research results indicated that CBT is effective as a prevention for adolescents with drinking alcoholic behavior, selfinjury, and HIV sufferers. There are significant behavioral changes in adolescents after getting CBT (Espositosmythers, Hadley, Curby, \& Brown, 2017).

Based on the previous explanation, it is expected that Group Cognitive Behavior Therapy (GCBT) can resolve the behavior of a problematic adolescents in order to shape directed and expected behavior. This therapy has never been executed at schools in Dharmasraya Regency to prevent the behavior of adolescents risked at drug abuse. For this reason, the researchers was intended to examine whether there was an influence of GCBT on behavior changes on adolescents risked at drug abuse in Dharmasraya Regency in 2019. 


\section{METHODS}

This study design was a Quasi Experimental research with Pretest and Posttest Two Group Design. This research compared two groups of adolescents who are at risk of drug abuse. The sampling technique in this study was purposive sampling technique. As many as 64 students fulfill the criteria of inclusion. Inclusion criteria include: willing to be a respondent, adolescents aged (13-18 years), adolescents at risk of abuse of cigarettes, alcohol, substances and drugs, adolescents who able to communicate well, cooperative, not experiencing a loss of consciousness during the study, willing to participate fully in following therapeutic procedures from start to finish.

From a population in the intervention group, 32 students were chosen as the sample which were taken from the working area of Sitiung 1 Public Health Center. Meanwhile, 32 students from Junior High School 02 Pulau Punjung and Senior High School 02 Pulau Punjung were chosen as the samples in the control group, who were selected from a population of 211 students. The characteristics of the respondents in the intervention group were similar to the control group. They had the highest case visits of behavior risked at drug abuse (cigarettes, alcohol, besides cigarettes and alcohol) in Health Care Services for Youth

The Assessment of substance Misuse in Adolescence (ASMA) was screening instrument to identify drug-use problems in adolescents (Willner, 2000). ASMA score is consists of 8 items, such as: (1) Frequently using substances or drugs (cigarettes, alcohol, glue/ gasoline), (2) Using substances or drugs with their own awareness, (3) Using substances or drugs because of boredom, anxiety, and loneliness, (4) Frequently thinking about the effects of consuming substances or the drugs, (5) Planning to use the substances or drugs every day, (6) Using more drugs to feel a higher effect, (7) Feeling irritable or anxious if not using the substances or drugs, and (8) Not being able to forget the substances or drugs when not consuming it within a certain period. ASMA scores are categorized as follows: $0=$ Not risky, $>8$ $11=$ Risky, $>12-16=$ drugs user.

The study was conduted from January - July 2019. The intervention of Group Cognitive Behavior Therapy was performed three times a week in three groups with different days in each group. The intervention group consists of three groups while the control group is only given health education. The intervention groups consist of 10-12 respondent. GCBT implemented in three sessions and time per session is $45-60$ minutes.

\section{RESULTS}

The results of this study consists of two parts: univariate and bivariate analysis which are described below. Univariate analysis included the characteristics of respondents (age and residence status) as well as the behavior of adolescents risked of drug abuse before and after getting the treatment to obtain the mean score and standard deviations from these variables by using paired sample t-tests.

Results of the frequency distribution of 64 respondents consisting of intervention groups and control groups based on age and residence status can be seen in table 1 . 
Table 1. The Frequency Distribution of Behavior Characteristics of Adolescents Risked of Drug Abuse $(n=64)$

\begin{tabular}{|c|c|c|c|c|c|c|c|}
\hline \multirow{3}{*}{ Variable } & \multirow{3}{*}{ Category } & \multicolumn{4}{|c|}{ Group } & \multirow{2}{*}{\multicolumn{2}{|c|}{ Number }} \\
\hline & & \multicolumn{2}{|c|}{ Interventions } & \multicolumn{2}{|c|}{ Control } & & \\
\hline & & $\mathbf{f}$ & $\%$ & f & $\%$ & $\mathbf{f}$ & $\%$ \\
\hline \multirow{2}{*}{ Age } & Early Adolescents & 10 & 31.2 & 11 & 34.4 & 21 & 32.8 \\
\hline & Late Adolescents & 22 & 68.7 & 21 & 65.6 & 43 & 67.2 \\
\hline
\end{tabular}

Table 1 showed that based on age, the late adolescents were dominated among 32 respondents in the intervention group.

The average behavior of adolescents risked at drug abuse before and after Group Cognitive Behavior Therapy was analyzed by using paired sample t-test. The results before the intervention are described in table 2 while the results after the intervention are described in table 3 .

Table 2. The Average of Behavior of Adolescents Risked of Drug Abuse before GCBT in Intervention and Control groups $(\mathrm{N}=64)$

\begin{tabular}{lcccc}
\hline \multirow{2}{*}{ Variable } & \multicolumn{2}{c}{$\begin{array}{c}\text { Intervention } \\
\text { Group } \\
(\mathbf{n = 3 2})\end{array}$} & \multicolumn{2}{c}{$\begin{array}{c}\text { Control } \\
\text { Group } \\
(\mathbf{n = 3 2})\end{array}$} \\
\cline { 2 - 5 } & Mean & SD & Mean & SD \\
\hline $\begin{array}{l}\text { Behavior of } \\
\text { Adolescents } \\
\text { risked of } \\
\text { drug abuse }\end{array}$ & 10,50 & 0,84 & 10,34 & 0,75 \\
\hline
\end{tabular}

Table 2 illustrates the analysis results which indicate that the average behavior risked of drug abuse in the control group is lower than in the intervention group.

Table 3 displays the analysis results finding that the average score of behavior of adolescents risked of drug abuse after getting CGBT in the intervention group is 7.91 with a standard deviation of 4.05. This indicates that the distance of data points with the mean score is quite high behavior after getting the intervention are 0 (no risk of drug abuse). Meanwhile, the behavior of adolescents risked of drug abuse after getting CGBT in the control group was 9.59 with a standard deviation of 2.61. These results indicate that the average behavior risked of drug abuse after getting the intervention in the intervention group is lower than the control group.

Table 3. The Average of Behavior of Adolescent Risked of Drug Abuse After GCBT in the Intervention and Control Groups $(\mathrm{N}=64)$

\begin{tabular}{|c|c|c|c|c|}
\hline \multirow[t]{2}{*}{ Variable } & \multicolumn{2}{|c|}{$\begin{array}{c}\text { Intervention } \\
\text { Group } \\
(\mathbf{n}=\mathbf{3 2})\end{array}$} & \multicolumn{2}{|c|}{$\begin{array}{l}\text { Control } \\
\text { Group } \\
(\mathbf{n}=\mathbf{3 2})\end{array}$} \\
\hline & Mean & SD & Mean & SD \\
\hline $\begin{array}{l}\text { Behavior of } \\
\text { Adolescents } \\
\text { risked of } \\
\text { drug abuse }\end{array}$ & 7.91 & 4.05 & 9.59 & 2.61 \\
\hline
\end{tabular}

Bivariate analysis was conducted by using t-test of independent sample t-test in order to examine the difference between the control and intervention groups in each of the variables before and after Group Cognitive Behavior Therapy (CGBT). The complete analysis results are as follows:

Independent sample t-test was conducted to understand differences in behavior of adolescent risked of drug abuse before and after the intervention in the intervention and the control groups. It can be seen in table 4 . 
Table 4. The Average of Behavior of Adolescents Risked of Drug Abuse Before and After GCBT in the Intervention and Control Groups $(\mathrm{N}=64)$

\begin{tabular}{|c|c|c|c|c|c|c|}
\hline \multirow{2}{*}{$\begin{array}{l}\text { Research } \\
\text { Variables }\end{array}$} & & \multirow{2}{*}{ Mean } & \multirow{2}{*}{ SD } & \multirow{2}{*}{$\begin{array}{c}\mathbf{P} \\
\text { Value }\end{array}$} & \multicolumn{2}{|c|}{ CI } \\
\hline & & & & & Lower & Upper \\
\hline $\begin{array}{l}\text { Group } \\
\text { Intervention }\end{array}$ & $\begin{array}{l}\text { Before } \\
\text { After }\end{array}$ & $\begin{array}{l}10.50 \\
7.91\end{array}$ & $\begin{array}{l}0.84 \\
4.05\end{array}$ & 0.001 & 1.13 & 4.05 \\
\hline Differences & & 2.59 & & & & \\
\hline $\begin{array}{l}\text { Control } \\
\text { Group }\end{array}$ & $\begin{array}{l}\text { Before } \\
\text { After }\end{array}$ & $\begin{array}{l}10.34 \\
9.59\end{array}$ & $\begin{array}{l}0.75 \\
2.61\end{array}$ & 0.124 & -.210 & -.224 \\
\hline Differences & & 0.75 & & & & \\
\hline
\end{tabular}

Table 4 explain the results of independent $t$ test which obtain $\mathrm{p}<0.05$ in the intervention group. This implies that there are significant differences in the average of behavior of adolescents risked of drug abuse. On the other hand, the results of independent $t$ test in the control group is $p>0.05$ which means that there is no significant difference in the average of behavior of adolescents risked of drug abuse.

The independent sample t-test was carried out to examine the differences in behavior of adolescents risked of drug abuse based on the age characteristics of the intervention and control group. It can be seen in the following table.

Table 5. The Average of Behavior of Adolescents Risked of Drug Abuse Before and After GCBT based on Age Categories in the Intervention Group ( $N=64)$

\begin{tabular}{|c|c|c|c|c|c|c|}
\hline \multirow{2}{*}{$\begin{array}{l}\text { Research } \\
\text { Variables }\end{array}$} & & \multirow{2}{*}{ Mean } & \multirow{2}{*}{ SD } & \multirow[t]{2}{*}{$P$ Value } & \multicolumn{2}{|c|}{ CI } \\
\hline & & & & & Lower & Upper \\
\hline \multirow[t]{2}{*}{ Early Adolescents } & Before & 9.90 & 0.87 & \multirow{2}{*}{0.33} & \multirow{2}{*}{-1.20} & \multirow{2}{*}{3.40} \\
\hline & After & 8.80 & 3.36 & & & \\
\hline Differences & & 1.10 & & & & \\
\hline \multirow[t]{2}{*}{ Late Adolescents } & Before & 10.77 & 0.68 & \multirow{2}{*}{0.001} & \multirow{2}{*}{1,38} & \multirow{2}{*}{5.16} \\
\hline & After & 7.50 & 4.34 & & & \\
\hline Differences & & 3.27 & & & & \\
\hline
\end{tabular}

Table 5 shows $\mathrm{p}$ value $<0.05$ which means that there are significant differences in the average of behavior of adolescents risked of drug abuse before and after CGBT in late adolescents. On the other hand, the average score of behavior of early adolescent is $\mathrm{p}>0.05$ which means that there is no significant difference in the average of behavior of adolescents risked of drug abuse before and after Group Cognitive Behavior Therapy (CGBT) in early adolescents.

\section{DISSCUSION}

The characteristics of respondents in this study were based on the age category. Early adolescence and late adolescence are the period of critical risk for the initiation of using substances and it allows to reach the peak for young people moving from adolescents to adults (BNN RI, 2018). The more respondents in the category of late adolescents, the greater possibility of respondents to be involved in drug abuse because the age of late adolescents is vulnerable for drug abuse. The age range of adolescents from 10 to 19 years is divided into two phases according to the World Health Organization (2015); they are early adolescents (10-14 years) and late adolescents (15-19) years. The results of this study show that the highest number of respondents are in the category of the late adolescent age group (15-19 years) who were included in the 
intervention group and the control group. This is because the most number of respondents came from $3^{\text {rd }}$ grade of Junior High School and 1st grade of Senior High School. Early adolescents and late adolescents are a critical risk period for the initiation of substance use and made it possible to culminate among young people who are moving from adolescents to adulthood (BNN RI, 2018). The more respondents who are in the late adolescence category, the possibility of respondents to engage in the abuse of drugs will be greater because the age of adolescents who will move toward maturity is possible for drug abuse.

The average of behavior of adolescents risked of drug abuse is illustrated by ASMA score which consists of 8 items and each respondent has a score $>8$. Before the intervention, it was found that there was an indication of risked behavior for drug abuse among respondents who were observed to frequently consume substances or drugs. These substances include cigarettes, wine/ beer, and glue/ gasoline. The data in the intervention group showed that the respondents who used cigarettes are as much as $100 \%$, drank wine/ beer are as much as $68.75 \%$ and used glue/ gasoline are as much as $12.5 \%$. Meanwhile, the respondents in the control group were also observed to use cigarettes for $100 \%$, drinking wine/ beer for $62.5 \%$, and using glue/ gasoline for $15.62 \%$. This result is in line with research conducted by Sitorus (2016) which found that smoking and drinking alcohol are the behaviors that motivate a person to drug abuse (Sitorus, 2016).

Based on the analysis results of the questionnaire in the instrument of ASMA, there are indications of the behavior of adolescents risked of drug abuse. Another research result based on questionnaire analysis before the intervention indicates the risk of drug abuse. For example, the respondents consumed substances or drugs by their own willingness $(81.3 \%)$. This result supports the result of a study conducted by Hawari (2009) which concludes that drug abuse can occur because of the interaction of predisposition factors originating from the person.

After the intervention, the results of this study showed a decrease in substances/ drugs use in the intervention group; for example, using cigarette was decreased to $78.12 \%$, drinking wine/ beer was decreased to $28.12 \%$, and none of the respondents used glue/ gasoline and consumed sleeping pills. Similar results were also obtained from the questionnaire, in which after the intervention, there were differences in the behavior of adolescents risked of drug abuse noticed from the intensity of the time consuming the substances or drugs.

This result is in line with research conducted by Hargiana et.al. (2018) which reveals that the decrease in smoking behavior, the level of nicotine dependence and anxiety of heads of the family of the smokers who get cognitive behavioral therapy is greater than those who do not get cognitive behavioral therapy. It is caused by a decrease in the smokers' habit of using cigarettes. CBT is also the most commonly used therapy for drug abuse patients (Carroll et al., 2008).

The decrease in behavior of adolescents risked of drugs in the intervention group was also occured because the teenagers had received GCBT. The analysis results prove that the hypothesis that there are significant changes in behavior of adolescents risked of drug abuse who get GCBT. The result of this research define that Group Cognitive Behavior Therapy affects not only the cognitive changes but also the behavior changes of adolescents risked at drug abuse. Thus, it is appropriate to be implemented for adolescents as a promotive and preventive mental health efforts carried out at school.

Based on the results of research, it was found that the average of behavior of adolescents risked of drug abuse after being given an intervention has decreased 
from "risked" to "not risked". Thus, there is a significant influence of group cognitive behavior therapy on behavior changes in late adolescents.

This result is in accordance with research from Patterson, and McDowell (2009) who state that Cognitive Behavioral Therapy is most effective for ages over 14 years although it can be used for children starting from 7 to 9 years. At this age, adolescents have more developed cognitive skills. Younger teens are usually better at responding to behavioral strategies than focusing on thinking strategies. Based on previous studies, it can be concluded that cognitive behavioral therapy is more effective or has an influence on the behavior of adolescents over 14 years.

The difference in behavior is influenced by changes in the mindset of respondents through the intervention of cognitive behavior therapy. CBT applies the theory and research on cognitive processes that cognitive behavioral therapists pay attention to the events in themselves, thoughts, perceptions, judgments, self-statements, unrealized material assumptions. They have studied and manipulated the processes as an effort to understand and change visible and invisible problematic behaviors (Oemarjoedi, 2003). As a result, the techniques implemented in Group Cognitive Behavior Therapy can reduce the intensity of the use of substances or drugs that are often used by the late adolescent respondents before getting the intervention, which is $54.5 \%$ and becomes $40.9 \%$ after the intervention.

This study obtained that $\mathrm{p}<0.05$ on the behavior of late adolescents risked at drug abuse, thus proving that GCBT has an influence on the behavior changes of late adolescents risked of drug abuse since they have cognitive maturity. Consequently, they are able to process their way of thinking better and obey the norms or rules that apply. On the other hand, there is no significant difference in the behavior of early adolescents risked of drug abuse because an approach such as supervision and attention from parents is required in order to anticipate the occurrence of drug abuse. It is because emotional and psychosocial development of the early adolescents is not mature yet. Parents have an important role in the emotional development of adolescents, especially the early adolescents. Moreover, GCBT can be implemented more effectively for the early adolescents if it is combined with family therapy.

\section{CONCLUSION}

Based on age, the characteristics of adolescents in Dharmasraya Regency in this research are dominated by late adolescents. The average of adolescent behavior before the intervention of Group Cognitive Behavior Therapy was risked of drug abuse. Meanwhile, the average of adolescent behavior after the intervention of Group Cognitive Behavior Therapy in the intervention group demonstrated a significant difference while in the control group, there was no significant difference.

Moreover, there are differences in the average of behavior of adolescents risked of drug abuse in the intervention group and the control group. The significant differences were found in the average behavior of late adolescents in the intervention group, whereas in early adolescents, there were no significant differences. This implies that Group Cognitive Behavior Therapy is more effective for late adolescents.

\section{ACKNOWLEDGEMENTS}

Many thanks to PPSDM Ministry of Health of the Republic of Indonesia who has given scholarships to researchers.

\section{REFERENCES}

BNN. (2015). Final Report of the 2014 National Survey on Drug Abuse Development. Jakarta - Indonesia.

BNN. (2018). Press Release End of Year 2018. Jakarta - Indonesia. 
Carroll, KM, Ph, D., Ball, SA, Ph, D., Martino, S., Ph, D., ... Rounsaville, BJ (2008) . Therapy for Addiction: A Randomized Trial of CBT4CBT, (July), 881-888.

Esposito-smythers, C., Hadley, W., Curby, TW, \& Brown, LK (2017). Behavior Research and Therapy Randomized pilot trial of cognitive behavioral alcohol, self-harm, and HIV prevention programs for teens in mental health treatment. Behavior Research and Therapy, 89, 49-56. https://doi.org/10.1016/j.brat.2016.11.0 $\underline{05}$.

Hargiana, G., Keliat, B. A., \& Mustikasari. (2018). The Effect of Cognitive Behavioral Therapy on Heads of Families' Smoking Behavior and Anxiety. Jurnal Keperawatan Indonesia, 21(2), 117-126. https://doi.org/10.7454/jki.v21i2.770

Hawari, D. (2006). Penyalahgunaan \& Ketergantungan NAZA (Narkotika, Alkohol \& Zat Adiktif) (Edisi Kedu). Jakarta: Balai Penerbit FKUI.

Litbangkes RI Ministry of Health. (2015). National School-Based Health Survey Results in Indonesia. Jakarta.

Martin, P, F. (2010). CBT Retrieved from http://www.minddisorders.com/BrDel/Cognitive-BehaviouralTherapy.html.

Oemarjoedi, A. K. (2003). Pendekatan Cognitive Behaviour Dalam Psikoterapi. Jakarta: Kreatif Media.

Patterson, K., and McDowell, C. (2009). Using precision teaching strategies to promote self-management of inner behavior and measuring effects on the symptoms of depression. University of Ulster, Coleraine, Northern Ireland.

Rapee, R., Wignall, A., Hudson, J., \& Schniering, C. (2000).Treating Anxious
Children And Adolescents: An Evidence-Based Approach. Oakland, CA: New Harbinger.

Sitorus, R. J. (2016). Use of Narcotics Supports Risk Behaviour. Jurnal Ilmu Kesehatan Masyarakat, 7(1), 1-5.

Stuart, G. W., Keliat, B. A., \& Pasaribu, J. (2016). Prinsip dan Praktik Keperawatan Kesehatan Jiwa Stuart. Singapore: Elsevier Ltd.

Susanti, H. (2010). Perubahan Perilaku dan Fungsi Kognitif dengan Terapi Perilaku Kognitif pada Penderita NAPZA.

Thomas, VS, \& Rockwood, KJ (2001). Alcohol Abuse, Cognitive Impairment, and Mortality Among Older People, 415-420.

United Nations Office on Drugs And Crime (UNODC). (2015). World Drug Report 2015.

World Health Organization; (WHO). (2015). World Health Statistics 2015. 